\title{
PENGARUH KEPEMILIKAN MANAJEMEN SERTA KEPEMILIKAN INSTITUSIONAL, PROFITABILITAS DAN KINERJA LINGKUNGAN (ENVIRONMENTAL PERFORMANCE) TERHADAP PENGUNGKAPAN CORPORATE SOCIAL RESPONSIBILITY (STUDI EMPIRIS PERUSAHAAN PERTAMBANGAN PERIODE 2015-2017).
}

\author{
Rury Rizki. H') $^{\text {) Afrizal }}{ }^{2)}$ Enggar D. P Arum ${ }^{3)}$ \\ ${ }^{1)}$ Alumni Magister Ilmu Akuntansi Pascasarjana Universitas Jambi 2019 \\ ${ }^{2) 3)}$ Dosen Pembimbing
}

\begin{abstract}
Corporate social responsibility or CSR is an investment for companies for the growth and sustainability (sustainability) of the company, it's no longer seen as a means of cost needed as a means to gain profits and company commitment to support the creation of sustainable development. This study discusses the main problems, namely the Influence of Management Ownership with Institutional Ownership, Profitability and Environmental Performance (Environmental Performance) on Corporate Social Responsibility Disclosures (Empirical Study of Mining Companies for the 2015-2017 period). The object in this study is the annual report on mining sector companies. This data contains financial reports and other data that support this research. Data obtained during the research are processed, analyzed and further processed on the basis of the theories that have been studied. Corporate Social Responsibility, related to the positive and significant profitability of Corporate Social Responsibility disclosures, related to Environmental Performance on Corporate Social Responsibility disclosures, a Relationship between Managerial Ownership, Institutional Ownership, Profitability and Environmental Performance is needed simultaneously on Corporate Social Responsibility in Indonesia. Mining Company on the Indonesia Stock Exchange
\end{abstract}

Keywords: Management Ownership, Institutional Ownership, Profitability, Environmental Performance and CSR Disclosure.

\begin{abstract}
ABSTRAK
Tanggung jawab sosial perusahaan atau CSR merupakan investasi bagi perusahaan untuk pertumbuhan dan keberlanjutan (sustainability) perusahaan, bukan dilihat lagi sebagai sarana biaya melainkan sebagai sarana meraih keuntungan serta komitmen perusahaan untuk mendukung terciptanya pembangunan berkelanjutan. Penelitian ini difokuskan kepada masalah pokok yaitu Pengaruh Kepemilikan Manajemen serta Kepemilikan Institusional, Profitabilitas dan Kinerja Lingkungan (Environmental Performance) Terhadap Pengungkapan Corporate Social Responsibility (Studi Empiris Perusahaan Pertambangan periode 2015-2017). Objek dalam penelitian ini adalah Laporan tahunan pada perusahaan sektor pertambangan. Data tersebut meliputi laporan keuangan serta data lainnya yang mendukung penelitian ini. Data yang diperoleh selama penelitian diolah, dianalisis dan diproses lebih lanjut dengan dasar teori yang ada dan dipelajari. Sehingga hasil penelitian menunjukkan bahwa terdapat pengaruh antara Kepemilikan Manajerial terhadap Pengungkapan Corporate Social Responsibility terdapat pengaruh antara Kepemilikan Institusional terhadap pengungkapan Corporate Social Responsibility, terdapat pengaruh positif dan signifikan Profitabilitas terhadap pengungkapan Corporate Social Responsibility, terdapat pengaruh antara Kinerja Lingkungan terhadap pengungkapan Corporate Social Responsibility, terdapat pengaruh antara Kepemilikan Manajerial, Kepemilikan Institusional, Profitabilitas dan Kinerja Lingkungan secara simultan terhadap Corporate Social Responsibility pada Perusahaan Pertambangan di Bursa Efek Indonesia
\end{abstract}

Kata Kunci: Kepemilikan Manajemen, Kepemilikan institusional, Profitabilitas, Kinerja Lingkungan dan Pengungkapan CSR. 


\section{PENDAHULUAN \\ 1.1 Latar Belakang}

Perusahaan harus dikelola secara benar, terukur dan sesuai dengan kepentingan perusahaan dengan tetap memperhitungkan kepentingan pemegang saham dan pihak pihak yang berkepentingan lainnya. Akuntabilitas merupakan prasyarat yang diperlukan untuk mencapai kinerja yang berkesinambungan. Program CSR merupakan investasi bagi perusahaan demi pertumbuhan dan keberlanjutan (sustainability) perusahaan dan bukan lagi dilihat sebagai saranabiaya melainkan sebagai sarana meraih keuntungan. Program CSR merupakan komitmen perusahaan untuk mendukung terciptanya pembangunan berkelanjutan (Rawi, 2008).

Munculnya beberapa kasus dikarenakan perusahaan dalam melaksanakan operasinya kurang memperhatikan kondisi lingkungan dan social disekitarnya, khususnya perusahaan yang aktivitasnya berkaitan dengan pengelolaan sumber daya alam (ekstraktif) sebagai contoh, PT Freeport Indonesia yang berlokasi di Papua yang memulai operasinya sejak tahun 1969, sampai dengan saat ini tidak lepas dari konflik berkepanjangan dengan masyarakat lokal, baik terkait dengan tanah ulayat, pelanggaran adat, maupun kesenjangan sosial dan ekonomi yang terjadi (Wibisono, 2007). Kasus Pencemaran Teluk Buyat, yaitu pembuangan tailing ke dasar laut yang mengakibatkan tercemarnya laut sehingga berkurangnya tangkapan ikan dan menurunnya kualitas kesehatan masyarakat lokal akibat operasional PT Newmont Minahasa Raya (NMR) tidak hanya menjadi masalah nasional melainkan internasional (Fauzi, 2008)

Masalah sosial dan lingkungan yang tidak diatur dengan baik oleh perusahaan ternyata memberikan dampak yang sangat besar, bahkan tujuan meraih keuntungan dalam aspek bisnis malah berbalik menjadi kerugian yang berlipat. Oleh karena itu masalah pengelolaan sosial dan lingkungan untuk saat ini tidak boleh dianggap marginal, atau aspek yang tidak dianggap penting dalam beroperasinya perusahaan. Tanggung jawab sosial perusahaan atau dikenal dengan istilah Corporate Social Responsibility, merupakan aspek penting yang harus dilakukan perusahaan dalam operasionalnya (Buga,2015).

Penelitian ini mencoba untuk melanjutkan penelitian Bangun $d k k$ (2012) dengan beberapa perbedaan berdasarkan saran dan keterbatasan penelitian sebelumnya yaitu: Pertama, variabel independen penelitian sebelumnya adalah Kepemilikan Manajemen, Kepemilikan Institusional Dan Profitabilitas. Sedangkan dalam penelitian ini penulis menambahkan variabel yang diduga mempengaruhi pengungkapan tanggungjawab sosial perusahaan (Corporate Social Disclousure) yaitu: Kinerja Lingkungan (Environmental Performance) serta variabel dependen menggunakan variabel Pengungkapan tanggungjawab sosial perusahaan (CSR).Kedua, penulis mecoba memperluas periode pengamatan dengan empat tahun periode pengamatan, agar dapat lebih menggambarkan kondisi pengungkapan corporate social responsibility di Indonesia.

Data yang digunakan dalam penelitian ini adalah mengambil data perusahaan-perusahaan Pertambangan dari tahun 2015 sampai tahun 2017 di Bursa Efek Indonesia Pengambilan data selama 3 tahun terhitung sejak 2015-2017 dengan alasan semakin banyak perusahaan yang menerbitkan sustainability report, namun ada juga perusahaan yang belum konsisten berturut-turut setiap periode. Penelitian dengan pengambilan tahun 2015-2017 dikarenakan ingin mengetahui tingkat konsistensi perusahaan yang menerbitkan laporan keberlanjutan pada periode baru atau 3 tahun silam terhitung dari tahun 2015.

Demi pemenuhan kepentingan shareholder dan stakeholder akan informasi dan manfaat sosial, UU No. 40 Tahun 2007 ini mengatur mengenai praktik dan pelaporan CSR. Pernyataan tersebut tercantum dalam Pasal 66 Ayat (2) Bagian C disebutkan bahwa selain menyampaikan laporan keuangan, perusahaan juga diwajibkan melaporkan pelaksanaan tanggung jawab sosial dan lingkungan. Sedangkan Pasal 74 menjelaskan kewajiban untuk melaksanakan tanggungjawab sosial dan lingkungan bagi perusahaan yang kegiatan usahanya berkaitan dengan sumber daya alam. Oleh karena itu, peneliti ingin memfokuskan penelitian kepada perusahaan yang kegiatan usaha utamanya atau core business berkaitan dengan sumber daya alam atau perusahaan pertambangan.

Perlakuan undang-undang tersebut mendorong perusahaan untuk bertanggungjawab terhadap lingkungan dan sosialnya. Adanya standar yang diberlakukan terhadap praktik pelaporan CSR (corporate social responsibility) akan menjadikan pengungkapan tanggung jawab sosial dan lingkungan menjadi mandatory disclosure, sehingga pelaporan CSR akan lebih lengkap dan akurat. Namun Undangundang tersebut masih memiliki kelemahan, yaitu sektor apa saja yang diwajibkan untuk melaksanakan CSR, sanksi yang dikenakan apabila melanggar, berapa besar anggaran minimum, serta format pelaporan CSR yang baik atau biasa disebut Good Corporate Governance $(G C G)$ atau tata kelola perusahaan yang baik.

Telah banyak penelitian terkait dengan pengaruh kepemilikan manajemn dan kepemilikan institusi seperti penelitian Wibowo (2016) tentang kepemilikan manajerial, kepemilikian institusional, kebijakan deviden dan kebijakan hutang terhadap nilai perusahan dari Hasil penelitian menunjukkan bahwa kepemilikan Manajerial berpengaruh negatif 
tidak signifikan terhadap nilai perusahaan, kepemilikan institusional berpengaruh positif signifikan terhadap nilai perusahaan, kebijakan deviden berpengaruh positif signifikan terhadap nilai perusahaan dan kebijakan hutang berpengaruh positif tidak signifikan terhadap nilai perusahaan yang terjadi pada perusahaan-perusahaan sektor manufaktur dalam Bursa Efek Indonesia (BEI) pada periode 2010 2014.

Penelitian ini mencoba untuk melanjutkan penelitian wibowo (2016) dengan beberapa perbedaan berdasarkan saran dan keterbatasan penelitian sebelumnya yaitu: Pertama, variabel independen penelitian sebelumnya adalah

1. Penelitian terdahulu periode yang dipakai 20102014, sedangkan penelitian ini periode yang dipakai 2015 - 2017 dimana periode yang berbeda tersebut keadaan ekonomi yang terjadi juga berbeda

2. Perbedaan dengan penelitian sebelumnya adalah digunakannya standard GRI 400 terbaru (Global Reporting Initiative) dalam mengukur Pengungkapan CSR di Penelitian ini.

Berdasarkan penelitian terdahulu penulis melihat bahwa penelitian tesebut berpengaruh negatif antara kepemilikian manajerial dan kepemilikan terhadap nilai prusahaan maka dari itu penulis tertarik untuk melihat kepemilikan manajemen dan kepemilikian institusional dari sudut pandang yang lain apakah pengaruhya negatif teradap pengungkapan Corporate social Responsibility selanjutnya penelitian serupa terkait dengan penelitian ini belum terlalu banyak maka dari itu peneliti tertarik untuk melakukan penelitian dengan judul" Pengaruh Kepemilikan Manajemen serta Kepemilikan Institusional, Profitabilitas dan Kinerja Lingkungan (Environmental Performance) Terhadap Pengungkapan Corporate Social Responsibility (Studi Empiris Perusahaan Pertambangan periode 2015-2017).

\subsection{Rumusan Masalah}

Berdasarkan latar belakang masalah, peneliti merumuskan masalah yang menjadi dasar penelitian ini adalah :

"Apakah terdapat pengaruh antara Kepemilikan Manajerial, Kepemilikan Institusional, Profitabilitas dan Kinerja Lingkungan secara simultan terhadap Corporate Social Responsibility pada Perusahaan Pertambangan di BEI".

\section{KAJIAN PUSTAKA, KERANGKA PEMIKIRAN DAN HIPOTESIS}

\subsubsection{Teori Legitimasi}

Legitimasi merupakan keadaan psikologis keberpihakan orang dan kelompok orang yang sangat peka terhadap gejala lingkungan sekitarnya baik fisik maupun non fisik. Hadi (2011) berpendapat legitimasi organisasi dapat dilihat sebagai sesuatu yang diberikan masyarakat kepada perusahaan dan sesuatu yang diinginkan atau dicari perusahaan dari masyarakat. Teori legitimasi merupakan manfaat atau sumberdaya potensial bagi perusahaan untuk bertahan hidup (going concern).

Gray et. al, (1996) ; Hadi (2011) menyatakan bahwa legitimasi merupakan sistem pengelolaan perusahaan yang berorientasi pada keberpihakan terhadap masyarakat (society), pemerintah individu dan kelompok masyarakat. Untuk itu, sebagai suatu sistem yang mengedepankan keberpihakan kepada society, operasi perusahaan harus kongruen dengan harapan masyarakat.

Sayekti dan Wondabio (2007) mengungkapkan bahwa dalam perusahaan memiliki kontrak dengan masyarakat untuk melakukan kegiatannya berdasarkan nilai-nilai justice, dan bagaimana perusahaan menanggapi berbagai kelompok kepentingan untuk melegitimasi tindakan perusahaan. Perusahaan semakin menyadari bahwa kelangsungan hidup perusahaan juga tergantung dari hubungan perusahaan tersebut dengan masyarakat dan lingkungan di mana perusahaan tersebut menjalankan setiap aktivitasnya. Dengan demikian, teori legitimasi merupakan salah satu teori yang mendasari pengungkapan CSR. Pengungkapan tanggung jawab sosial perusahaan dilakukan untuk mendapatkan nilai positif dan legitimasi dari masyarakat.

\subsubsection{Teori Stakeholder}

Stakeholder adalah semua pihak baik internal maupun eksternal yang memiliki hubungan baik bersifat memengaruhi maupun dipengaruhi, bersifat langsung maupun tidak langsung oleh perusahaan. Misalnya pemerintah, pesaing, masyarakat, lingkungan internasional, lembaga pemerhati lingkungan, pekerja, dsb. Perusahaan hendaknya memperhatikan stakeholder karena mereka adalah pihak yang berhubungan dengan aktivitas serta kebijakan yang diambil perusahaan. Teori stakeholder menjelaskan bahwa perusahaan tidak hanya bertanggungjawab kepada para pemilik (shareholder), namun lebih luas sampai pada sosial kemasyarakatan (stakeholder). Sehingga tanggungjawab perusahaan tidak hanya diukur pada indikator ekonomi (economic focused) dalam laporan keuangan, tapi juga memperhitungkan faktor-faktor sosial (social dimentions) terhadap stakeholder internal dan eksternal. 
Esensi teori stakeholder tersebut di atas jika dihubungkan dengan teori legitimasi yang mengisyaratkan bahwa perusahaan hendaknya mengurangi expectation gap dengan masyarakat (publik) sekitar guna meningkatkan legitimasi (pengakuan) masyarakat, ternyata terdapat benang merah. Perusahaan hendaknya menjaga reputasinya yaitu dengan menggeser pola orientasi (tujuan) yang semula semata-mata diukur dengan economic measurement yang cenderung shareholder (para pemilik) berorientasi dengan memperhitungkan faktor sosial (social factors) sebagai wujud kepedulian dan keberpihakan terhadap masalah sosial kemasyarakatan (stakeholder orientation). Hadi, (2011) menyatakan bahwa teori stakeholder merupakan pihak yang berkepentingan terhadap perusahaan yang dapat mempengaruhi atau dapat dipengaruhi oleh aktivitas perusahaan. Kepemilikan institusional yang besar akan sangat berpengaruh dan berdampak pada keputusan manajemen yang akan diambil. Salah satu keputusannya adalah pengungkapan informasi CSR.

\subsubsection{Pengungkapan $C S R$}

\subsubsection{Definisi Pengungkapan Corporate Social Responsibility}

The World Bussines Council For Sustainable Development dalam Luthan (2010) sebagai berikut, "Continuing commitment by business to behave ethically and contribute to economic development while improving the quality of life of the workface and their families as well as of the local community and society at large". Definisi tersebut menjelaskan CSR adalah sebuah komitmen berkelanjutan yang dilandasi oleh perilaku etik bisnis berupa kontribusi pada pembangunan ekonomi dalam meningkatkan kualitas kehidupan masyarakat sekitar dan masyarakat luas pada umumnya Sedangkan pengungkapan (disclousure) sebagai penyediaan sejumlah informasi yang dibutuhkan untuk pengoperasian secara optimal pasar modal efisien.

Purwanto (2011) menyatakan ada dua macam pengungkapan yaitu, pengungkapan yang bersifat wajib (mandatory) yaitu pengungkapan informasi yang wajib dilakukan oleh perusahaan yang didasarkan pada peraturan atau standar tertentu, Pengungkapan sukarela (voluntary) dilakukan perusahaan untuk memenuhi keinginan stakeholder meskipun menambah cost perusahaan namun, banyak manfaat yang diperoleh dari pengungkapan sukarela antara lain meningkatkan citra perusahaan, meningkatkan kredibilitas perusahaan, membantu investor dalam memahami strategi bisnis manajemen, menarik perhatian analis, meningkatkan akurasi pasar, menurunkan ketidaksimetrisan informasi pasar dan menurunkan kejutan pasar

Pengungkapan CSR menurut Mathews (1995); Purwanto (2011) yaitu merupakan proses pengkomunikasian dampak sosial dan lingkungan dari kegiatan ekonomi organisasi terhadap kelompok khusus yang berkepentingan dan terhadap masyarakat secara keseluruhan. Sebagian perusahaan bahkan menganggap bahwa mengomunikasikan atau mengungkpankan CSR sama pentingnya dengan kegiatan CSR itu sendiri. Dengan mengkomunikasikan kegiatan CSR semakin banyak masyarakat yang mengetahui investasi sosial perusahaan shingga tingkat risiko perusahaan menghadapi gejolak sosial akan menurun. Jadi mengungkapkan CSR kepada umum akan menigkatkan nilai social hedging perusahaan.

Seiring dengan kepedulian masyarakat terhadap lingkungan dan sosial, maka harus ada standar dan regulasi yang jelas tentang pengungkapan CSR, agar terciptanya keseragaman dalam melakukan pelaporan sosial dan lingkungan sehingga CSR akan mudah terukur untuk kepentingan penilaian kinerja perusahaan tentunya. Standar pengungkapan CSR kini semakin pesat berkembang, dibuktikan dengan munculnya beberapa indikator atau standar dalam pelaporan sosial. Dari banyaknya standar pengungkapan, Global Reporting Initiative Sustainability reporting Guidelines adalah standar pengungkapan yang diterima umum dan digunakan oleh banyak perusahaan. Global Reporting Intiative (GRI) adalah sebuah jaringan berbasis organisasi yang telah mempelopori perkembangan dunia, paling banyak menggunakan kerangka laporan berkelanjutan dan berkomitmen untuk terus-menerus melakukan perbaikan dan penerapan di seluruh dunia (Suharto,2013)

\subsubsection{Komponen Dasar Pengungkapan Corporate Social Responsibility}

CSR dibagi menjadi tiga komponen utama, yaitu: people, profit, dan planet. Ketiga komponen ini yang kerap dijadikan dasar perencanaan, implementasi dan evaluasi (pelaporan) programprogram CSR yang kemudian dikenal sebagai Triple Bottom Line.Triple bottom line merupakan sinergi dari tiga elemen yang merupakan komponen dasar dari pelaksanaan dan pengungkapan CSR.

Pengungkapan corporate social responsibility adalah pengungkapan informasimengenai tanggung jawab perusahaan di dalam laporan tahunan. Instrumenpengukuran yang akan digunakan dalam penelitian ini mengacu pada pedoman GRI G4 yaitu 91 item pengungkapan yang diterbitkan pada tanggal 22 Mei 2013. Pengukuran variabel ini dengan indeks pengungkapan sosial, selanjutnya ditulis CSR dengan membandingkan jumlah pengungkapan yang diharapkan. Pengungkapan sosial merupakan data yang diungkap oleh perusahaan berkaitan dengan aktifitassosialnya yang meliputi 9 item kategori ekonomi, 34 item kategori lingkungan, 16 item kategori sosial sub-kategori:praktek ketenagakerjaan dan kenyamanan bekerja, 12 item sub-kategori:hak asasi manusia, 11 item sub kategori:masyarakat, 9 
item sub-kategori:tanggungjawab atas produk dengan total 91 item.

Tabel 1.

The Triple Bottom Line of Corporate Social Responsibility Disclousure

\begin{tabular}{|c|c|c|c|}
\hline & People & Profit & Planet \\
\hline $\begin{array}{l}\text { Defin } \\
\text { isi }\end{array}$ & $\begin{array}{l}\text { Sebuah } \\
\text { bisnis } \\
\text { harus } \\
\text { bertanggun } \\
\mathrm{g} \text { jawab } \\
\text { untuk } \\
\text { memajuka } \\
\mathrm{n} \text { dan } \\
\text { mensejahte } \\
\text { rakan serta } \\
\text { sosial se } \\
\text { seluruh } \\
\text { stakeholde } \\
\text { rnya. }\end{array}$ & $\begin{array}{l}\text { Perusahaan } \\
\text { tidak boleh } \\
\text { hanya } \\
\text { memiliki } \\
\text { keuntungan } \\
\text { bagi } \\
\text { organisasiny } \\
\text { a saja tetapi } \\
\text { harus dapat } \\
\text { memberikan } \\
\text { kemajuan } \\
\text { ekonomi } \\
\text { bagi para } \\
\text { stakeholder- } \\
\text { nya }\end{array}$ & $\begin{array}{l}\text { Perusahaan } \\
\text { harus dapat } \\
\text { menggunakan } \\
\text { sumber daya } \\
\text { alam dengan } \\
\text { sangat } \\
\text { bertanggung } \\
\text { jawab menjaga } \\
\text { keadaan } \\
\text { lingkungan } \\
\text { serta } \\
\text { memperkecil } \\
\text { jumlah limbah } \\
\text { produksi. }\end{array}$ \\
\hline $\begin{array}{l}\text { Jenis } \\
\text { Kegi } \\
\text { atan }\end{array}$ & $\begin{array}{l}\text { Kegiatan } \\
\text { kedermaw } \\
\text { anan yang } \\
\text { dilakukan } \\
\text { secara } \\
\text { tulus untuk } \\
\text { membangu } \\
\mathrm{n} \\
\text { masyarakat } \\
\text { dan } \\
\text { sumber } \\
\text { daya } \\
\text { manusia. }\end{array}$ & $\begin{array}{l}\text { Tindakan } \\
\text { perusahaan } \\
\text { untuk terjun } \\
\text { langsung di } \\
\text { dalam } \\
\text { masyarakat } \\
\text { untuk } \\
\text { memperkuat } \\
\text { ketahanan } \\
\text { ekonomi }\end{array}$ & $\begin{array}{l}\text { Penerapan } \\
\text { proses produksi } \\
\text { yang bersih, } \\
\text { aman dan } \\
\text { bertanggung } \\
\text { jawab. }\end{array}$ \\
\hline $\begin{array}{l}\text { Cont } \\
\text { oh }\end{array}$ & $\begin{array}{l}\text { 1.Beasiswa } \\
\text { Pendidika } \\
2 . \\
\text { Pelayanan } \\
\text { Kesehatan }\end{array}$ & $\begin{array}{l}\text { Pembinaan } \\
\text { UKM } \\
\text { Bantuan } \\
\text { Modal dan } \\
\text { Kredit } \\
\text { Pemberdaya } \\
\text { an Lokal }\end{array}$ & $\begin{array}{l}\text { Pengelolaan } \\
\text { Limbah } \\
\text { Penanaman } \\
\text { Pohon } \\
\text { Kampanye } \\
\text { Lingkungan } \\
\text { Hidup }\end{array}$ \\
\hline
\end{tabular}

Sumber : Hasibuan (2006).

Gambar 1.

Model Penelitian

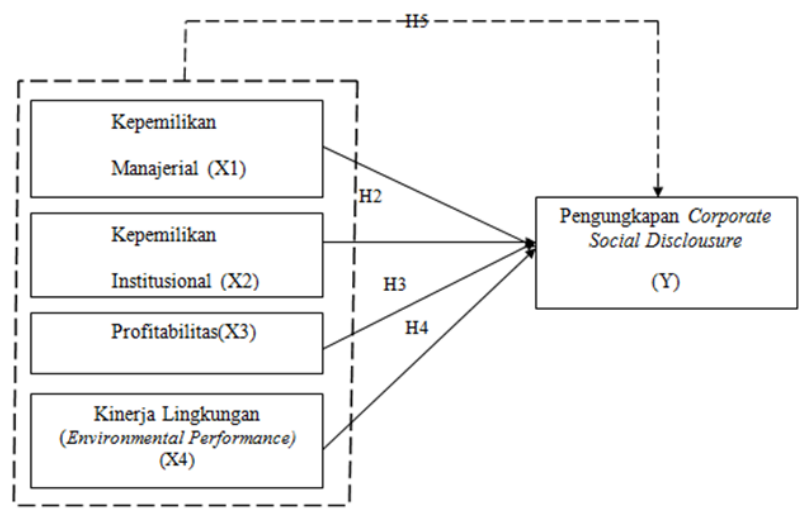

\section{METODOLOGI PENELITIAN}

Objek dalam penelitian ini adalah adalah Laporan tahunan pada perusahaan yang pertambangan batu bara periode 2015- 2017 dengan data dan informasi yang dibutuhkan berhubungan dengan pengungkapan tanggung jawab sosial perusahaan (CSR), kepemilikan manajerial, kepemilikan institusional, profitabilitas dan kinerja lingkungan. Data tersebut meliputi laporan keuangan serta data lainnya yang mendukung penelitian ini. Data yang diperoleh selama penelitian akan diolah, dianalisis dan diproses lebih lanjut dengan dasar teori yang ada dan dipelajari.

Penulis memilih Perusahaan pertambangan pada tahun 2015-2017 karena perusahaan-perusahaan pertambangan Batu Bara yang memiliki Corporate Sustainbility Report (CSR) atau laporan keberlanjutan baik dalam bentuk terpisah maupun laporan tahunan perusahaan (annual report) dan pemilihan perusahaan ini adalah untuk melihat apakah penerapan G4 Global Reporting Initiatif Guidelines (G4GRI) dan bagaimana pengaruh kepemilikan manajerial, kepemilikan institusional, profitabilitas dan kinerja lingkungan terhadap pengungkapan tanggung jawab sosial perusahaan atau CSR.

Populasi adalah keseluruhan orang, kejadian atau sesuatu yang menarik yang ingin peneliti investigasi (Sekaran, 2010). Populasi pada dasarnya merupakan objek yang diteliti. Adapun yang dijadikan populasi dalam penelitian ini adalah data laporan Corporate Social Responsibility (CSR) dan laporan keuangan tahun 2015 sampai dengan 2017 pada perusahaan pertambangan yang tercatat di Bursa Efek Indonesia sebanyak 43 Perusahaan.

Sampel adalah bagian dari populasi yang dianggap dapat mewakili populasinya. Adapun sampel penelitian ini adalah laporan Corporate Social Responsibility (CSR) dan laporan keuangan pada perusahaan pertambangan yang tercatat di Bursa Efek Indonesia, sebanyak 24 perusahaan selama 3 tahun dimulai dari tahun 2015 sampai dengan tahun 2017. Pemilihan sampel dengan menggunakan teknik random sampling atau sampel secara acak. Pengambilan sampel tersebut dipilih karena kelengkapan data untuk penelitian.

Kriteria-kriteria atas sampel dalam penelitian ini adalah sebagai berikut:

1. Perusahaan pertambangan yang menerbitkan Annual Report tahun 2015-2017.

2. Laporan keuangan di ambil berdasarkan laporan keuangan triwulan.

3. Perusahaan yang listing di Bursa Efek Indonesia periode 2015-2017 secara berturut-turut

4. Melakukan Pengungkapan CSR dalam Tahun 2015- 2017. 
Selanjutnya secara lebih rinci kriteria untuk pengambilan sample tersebut adalah :

\begin{tabular}{|c|l|c|}
\hline No & \multicolumn{1}{|c|}{ Kriteria Pemilihan Sampel } & Jumlah Perusahaan \\
\hline 1 & $\begin{array}{l}\text { Seluruh Perusahaan Pertambangan dari } \\
\text { berbagai sektor yang Terdaftar di BEI } \\
\text { tahun 2015-2017 } \\
\text { Perusahaan Pertambangan dari berbagai } \\
\text { sektor yang Terdaftar di BEI tahun 2015- } \\
\text { 2017 yang tidak mengungkapkan CSR } \\
\text { Sehingga sampel yang diambil adalah }\end{array}$ & 43 \\
$\begin{array}{l}\text { PerusahaanPertambangan dariberbagai } \\
\text { sektor yang mengungkapkan CSR }\end{array}$ & \\
\hline
\end{tabular}

Berdasarkan kriteria tersebut maka dihasilkan 24 perusahaan yaitu: PT.Adaro Energy ,Tbk PT. Atlas Resources,Tbk, PT. Bara Jaya Internasional,Tbk, PT. Borneo Lumbung Energi \&Metal,Tbk, PT. Borneo Sukses Sarana,Tbk., PT. Bumi Resources,Tbk, PT. Bayan Resources, Tbk., PT. Darma Henwa,Tbk ,PT. Delta Dunia Makmur, Tbk , PT. Dian Swastatika Sentosa,Tbk., PT. Dwi Guna Laksana, Tbk , PT, Alfa Energi Investama, Tbk PT. Golden Energy Mines, Tbk PT. Garda Tujuh Buana,Tbk PT. Harum Energy, Tbk, PT. Indo Tambangraya Megah,Tbk PT.Resources Alam Indonesia,Tbk PT. Mitrabara Adiperdana, Tbk, PT.Myoh Technology,Tbk PT. Perdana Karya Perkasa, Tbk, PT. Bukit Asam ,Tbk , PT. Petrosea dan PT. Golden Eagle Energy, Tbk

\section{HASIL DAN PEMBAHASAN}

\subsection{Hasil Uji Multikolinieritas}

\subsubsection{Uji Normalitas}

Tujuan uji normalitas adalah untuk mengetahui apakah data dari sampel penelitian berasal dari populasi yang berdistribusi normal atau tidak. Uji normalitas dilakukan menggunakan teknik uji Liliefors atau dalam program SPSS disebut dengan Kolmogrov-Smirnov. Kriteria dari uji normalitas adalah bahwa data berdistribusi normal jika nilai $\mathrm{L}_{\text {hitung }}<\mathrm{L}_{\text {tabel }}$ atau nilai signifikansi $>0,05$.

Dalam penelitian ini data menunjukkan berdistribusi normal, hal ini terlihat dari nilai signifikan yang lebih besar dari 0,05 . Untuk lebih jelas dapat dilihat pada tabel di bawah ini:
Tabel 2.

One-Sample Kolmogorov-Smirnov Test

\begin{tabular}{|ll|r|}
\hline & & $\begin{array}{r}\text { Unstandardized } \\
\text { Predicted Value }\end{array}$ \\
\hline & & 72 \\
$\mathrm{~N}$ & Mean &, 3236479 \\
Normal & Std. &, 02461271 \\
Parameters & Deviation &, 093 \\
Most & Absolute &, 093 \\
Extreme & Positive &,- 072 \\
Differences & Negative &, 786 \\
Kolmogorov-Smirnov Z &, 567 \\
Asymp. Sig. (2-tailed)
\end{tabular}

a. Test distribution is Normal.

b. Calculated from data.

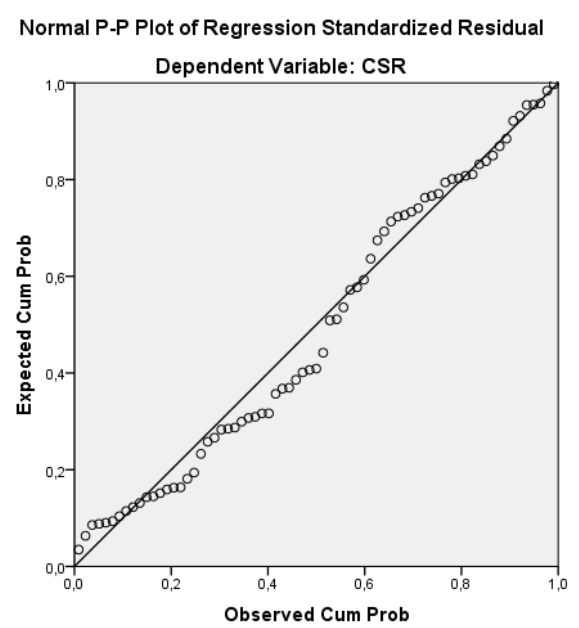

Melihat tampilan grafik normal P-Plot Og regression standadized resudual di atas, terlihat titik titik menyebar di sekitar garis diagonal, serta penyeberannya tidak menjauh dari garis diagonal yang berarti grafik normal p. Plot of regression standadized residual menunjukan model berdistribusi normal

\subsubsection{Uji Linieritas}

Tujuan uji linieritas adalah unruk mengetahui bagaimana bentuk hubungan antara satu variable bebas dengan satu variable terikat. Adapun hasil uji linieritas dan keberartian regresi linier yang dilakukan menggunakan alat bantu SPSS versi 22 adalah sebagai berikut:

Bila $\alpha$ yang ditentukan adalah 5\%, maka berdasarkan keluaran di atas, dapat disimpulkan bahwa data yang dipergunakan dapat dijelaskan oleh regresi linier dengan cukup baik karena nilai Sig. linearity data tersebut adalah sebesar 0,006 (lebih kecil dari 0,05) dan nilai Sig. deviation from linearity data tersebut adalah sebesar 0,072 (lebih besar dari 0,05) 
Tabel 3.

ANOVA Table

\begin{tabular}{|r|r|r|r|r|}
\hline $\begin{array}{c}\text { Sum of } \\
\text { Squares }\end{array}$ & df & $\begin{array}{c}\text { Mean } \\
\text { Square }\end{array}$ & F & Sig. \\
\hline, 319 & 65 &, 005 & 3,408 &, 062 \\
, 025 & 1 &, 025 & 17,161 &, 006 \\
, 295 & 64 &, 005 & 3,194 &, 072 \\
, 009 & 6 &, 001 & & \\
, 328 & 72 & & & \\
\hline
\end{tabular}

Bila $\alpha$ yang ditentukan adalah 5\%, maka berdasarkan keluaran di atas, dapat disimpulkan bahwa data yang dipergunakan dapat dijelaskan oleh regresi linier dengan cukup baik karena nilai Sig.linearity data tersebut adalah sebesar 0,006 (lebih kecil dari 0,05) dan nilai Sig. deviation from linearity data tersebut adalah sebesar 0,072 (lebih besar dari 0,05)

\subsubsection{Uji Multikolonieritas}

Multikolinearitas adalah suatu keadaan dimana satu atau lebih variabel independent terdapat korelasi atau hubungan dengan variabel independent lainnya atau dengan kata lain satu atau lebih variabel independent merupakan satu fungsi linear dari variabel independenlainnya. Salah satu cara untuk menganalisis ada atau tidaknya pengaruh multikolinearitas dalam penelitian ini dengan melihat nilai tolerance.

Tabel 4.

\section{Uji Multikolonieritas}

\begin{tabular}{|c|c|c|c|c|c|c|c|}
\hline \multirow{3}{*}{ Model } & \multicolumn{4}{|c|}{ Coefficients ${ }^{2}$} & \multirow{3}{*}{ Sig. } & \multirow{2}{*}{\multicolumn{2}{|c|}{$\begin{array}{c}\text { Collinearity } \\
\text { Statistics }\end{array}$}} \\
\hline & \multicolumn{2}{|c|}{$\begin{array}{l}\text { Unstandardized } \\
\text { Coefficients }\end{array}$} & \multirow{2}{*}{\begin{tabular}{|c|c|}
$\begin{array}{c}\text { Standard } \\
\text { ized } \\
\text { Coefficie } \\
\text { nts }\end{array}$ \\
Beta \\
\end{tabular}} & \multirow[t]{2}{*}{$\mathrm{t}$} & & & \\
\hline & B & $\begin{array}{c}\text { Std. } \\
\text { Error }\end{array}$ & & & & $\begin{array}{c}\text { Tolerane } \\
e\end{array}$ & VIF \\
\hline (Constant) &, 237 &, 065 & & $\begin{array}{r}3,67 \\
3\end{array}$ &, 000 & & \\
\hline $\mathrm{KM}$ &, 044 &, 021 &, 248 & $\begin{array}{r}2,06 \\
3\end{array}$ &, 043 & 910, & $\begin{array}{r}1,09 \\
9\end{array}$ \\
\hline $\mathrm{KI}$ &,- 024 &, 020 &,- 143 & 1,18 &, 242 & ,898 & $\begin{array}{r}1,11 \\
3\end{array}$ \\
\hline Profit &,- 033 &, 042 &,- 089 &, 777 &, 440 & 996 & $\begin{array}{r}1,00 \\
4\end{array}$ \\
\hline $\mathrm{KL}$ &, 020 &, 015 &, 157 & $\begin{array}{r}1,34 \\
7\end{array}$ &, 182 & ,961 & $\begin{array}{r}1,04 \\
0\end{array}$ \\
\hline
\end{tabular}

Berdasarkan Output diatas diketahui bahwa nilai tolerance variabel (X1), (X2), (X3) dan (X4) yakni 0,$910 ; 0,898 ; 0,996$ dan 0,961 lebih besar dari 0,10 sementara itu nilai VIF variabel X1,X2, X3 dan X4 yakni 1,$099 ; 1,113 ; 1,004$ dan 1,040 lebih kecil dari 10. Dapat disimpulkan tidak terjadi multikolonieritas.

\subsubsection{Uji Autokorelasi}

Uji autokorelasi bertujuan untuk menguji apakah model regresi linier ada korelasi antara kesalahan pengganggu pada periode $t$ dengan kesalahan pengganggu t-1 (sebelumnya). Jika terjadi korelasi, maka terjadi problem autokorelasi. Autokorelasi muncul karena observasi yang berurutan sepanjang waktu berkaitan satu sama lainnya. Model regresi yang baik adalah regresi yang bebas dari autokorelasi (Ghozali, 2011). Uji autokorelasi dilakukan dengan Uji autokorelasi dengn durbin watson:

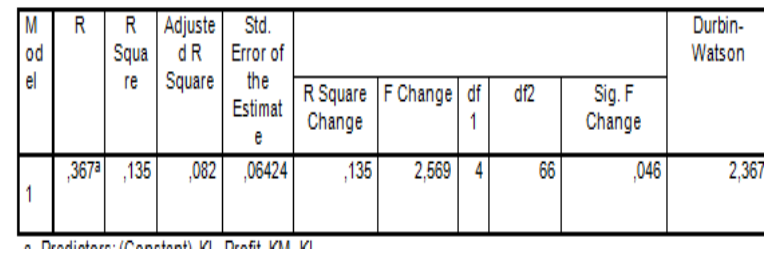

Nilai Durbin Watson pada tabel summary tersebut adalah nilai Durbin Watson hitung yang nantinya akan anda bandingkan dengan nilai Durbin Watson (DW) Tabel, baik nilai DU (Durbin Upper) maupun nilai DL (Durbin Lower). Dan dapat disimpul kan nila tabel DW adalah untuk 72 adalah 1,586 artinya nilai durbin lebih besar dari Nilai DW tabel artinya tidak terdapat Auto korelasi.

\subsection{Analisis Regresi Linier Berganda}

Melihat pengaruh variabel Kepemilikan Manajerial (X1), Kepemilikan Institusional (X2) dan Profitabilitas (X3) dan Kinerja Lingkungan (X4) terhadap Pengungkapan CSR (Y) digunakan analisis regresi berganda dengan persamaan sebagai berikut:

$\mathrm{Y}=0,185+0,38 \mathrm{X} 1+0,037 \mathrm{X} 2+0,051 \mathrm{X} 3+0,065$ $\mathrm{X} 4+\mathrm{e}$

1. Dari hasil pengolahan data maka semua variabel tersebut diatas menunjukkan adanya pengaruh yang positif dan signifikan, hal ini dapat dilihat dari nilai probabilitas $(\alpha<0,05)$. Model regresi di atas menunjukkan bahwa setiap kenaikan $1 \%$ Kepemilikan Manajerial akan meningkatkan Pengungkapan CSR 0,037\%,. Dan sebaliknya jika kepemilikikan Manajerial turun sebesar 1\%, maka CSR juga diprediksi mengalami penurunan sebesar 0,037\% dengan anggapan variable Kepemilikan institusional dan Profitabilitas dan Lingkungan Kerja tetap (ceteris paribus). Untuk lebih jelasnya dapat dilihat pada table dibawah ini

2. Model regresi di atas menunjukkan bahwa setiap kenaikan 1\% Kepemilikan Manajerial akan meningkatkan Pengungkapan CSR 0,037\%,. Dan sebaliknya jika kepemilikikan Manajerial turun sebesar 1\%, maka CSR juga diprediksi mengalami penurunan sebesar 0,037\% dengan anggapan variable Kepemilikann institusional dan Profitabilitas dan Lingkungan Kerja tetap (ceteris paribus).

3. Untuk uji signifikan dapat dilihat pada angka Sig (besaran nilai probabilitas). Jika probabilitas > 0,025 maka Ho diterima dan sebaliknya jika probabilitas < 0,025 maka Ho ditolak. Jadi, berdasarkan tabel Sig dengan nilai $0,000<0,025$ maka Ho ditolak dan Ha diterima. 


\subsubsection{Hasil pengujian hipotesis (Uji F)}

Kepemilikan Manajerial, kepemilikan Institusional, Profitabilitas dan Kinerja Lingkungan secara simultan berpengaruh terhadap Pengungkapan CSR . Apabila $F_{\text {hitung }}$ lebih besar dari pada $F_{\text {tabel }}$ maka $\mathrm{H}_{\mathrm{o}}$ ditolak. Pengujian ini dilakukan dengan membandingkan $\mathrm{F}_{\text {hitung }}$ dengan $\mathrm{F}_{\text {tabel }}$ :

Tabel 5.

ANOVA ${ }^{a}$

\begin{tabular}{|c|c|c|c|c|c|}
\hline Model & $\begin{array}{c}\text { Sum } \\
\text { of } \\
\text { Square } \\
\text { s }\end{array}$ & $\mathrm{df}$ & $\begin{array}{l}\text { Mean } \\
\text { Square }\end{array}$ & $\mathrm{F}$ & Sig. \\
\hline $\begin{array}{l}\text { Regres } \\
\text { sion }\end{array}$ &, 113 & 4 &, 028 & $\begin{array}{r}9,27 \\
3\end{array}$ &, $000^{6}$ \\
\hline $\begin{array}{l}1 \text { Residu } \\
\text { al }\end{array}$ & ,202 & 66 & ,003 & & \\
\hline Total & ,315 & 70 & & & \\
\hline
\end{tabular}

a. Dependent Variable: CSR

b. Predictors: (Constant), Profit ,KM, KL, KI

Dari tabel diatas diketahui nilai $F_{\text {hitung }}$ sebesar 9,273. Nilai $f_{\text {tabel }}$ dapat dilihat pada tabel statistik dengan taraf signifikansi 0.05 dengan derajat kebebasan (df1) k-1atau 6-1=5, (df2) n-k atau 72$5=67$, nilai $\mathrm{f}_{\text {tabel }}$ yang diperoleh sebesar 2.240 sehingga $f_{\text {hitung }}>f_{\text {tabel }}$ yaitu sebesar $(9,273>2.240$ maka $\mathrm{H}_{0}$ ditolak dan menerima $\mathrm{H}_{\alpha}$, dengan tingkat signifikan sebesar $0.000(<0.05)$. Maka pengujian diatas menunjukkan bahwa terdapat pengaruh antara Kepemilikan Manajerial, Kepemilikan Institusional, Profitabilitas dan Kinerja Lingkungan secara simultan terhadap Corporate Social Responsibility pada Perusahaan Pertambangan di BEI Analisi yang digunakan adalah analisis regresi berganda. dari hasil perhitungan dengan bantuan SPSS 22 diperoleh hasil koefesien korelasi berikut: dari hasil perhitungan dengan bantuan SPSS 22 diperoleh hasil koefesien korelasi berikut: Pengungkapan CSR yang dihitung dengan korelasi adalah 0,275, sedangkan variabel Kepemilikan Institusonal dengan Pengungkapan CSR menunjukkan hasil hubungan sebesar 0,234 serta hubungan antara Profitalitas terhadap Pengungkapan CSR sebsesar 0,473 Secara teoritis, karena korelasi Profitabilitas perusahan lebih besar, maka variabel Profitabilitas Perusahan memiliki pengaruh besar terhadap Pengungkapan CSR dibandingkan denga variabel Kepemilikan Institusional dan kepemilikan Manajerial dan Kinerja Lingkungan.

\subsubsection{Koefisien Determinasi $\left(\mathbf{R}^{\mathbf{2}}\right)$}

Tingkat signifikansi koefesien regresi dapat diukur dari nilai probabilitas menghasilkan angka dibawah 0,000 atau praktis $0,000<0,05$, maka regresi diantara variabel Kepemilikan Manajerial, Kepemilikan Institusional, Profitabilitas dan Kinerja Lingkungan terhadap Pengungkapan CSR sangat signifikan. Menurut Ghozali (2011) koefisien determinasi $\left(\mathrm{R}^{2}\right)$ dilakukan untuk melihat seberapa jauh kemampuan model dalam menerangkan variasi variabel dependen. Kelemahan mendasar penggunaan koefisien determinasi $\left(\mathrm{R}^{2}\right)$ adalah bias terhadap jumlah variabel independen yang dimasukkan kedalam model. Setiap tambahan satu variabel independen, maka $\mathrm{R}^{2}$ pasti meningkat tidak perduli apakah variabel tersebut berpengaruh secara signifikan terhadap variabel dependen. Oleh karena itu banyak peneliti menganjurkan untuk menggunakan nilai adjusted $R$ square pada saat mengevaluasi mana model regresi terbaik. Tidak seperti $\mathrm{R}^{2}$, nilai adjusted $R$ square dapat naik atau turun apabila satu variabel independen ditambahkan kedalam model. Berikut merupakan hasil pengujian determinasi berganda yang disajikan pada tabel berikut ini:

Tabel 6.

Koefesien Determinasi Regresi Variabel Kepemilikan Manajerial (X1), Kepemilikan Institusional (X2) Profitabilitas (X3) dan Kinerja Lingkungan (X4) Terhadap Pengungkapan CSR(Y)

Model Summary

\begin{tabular}{|l|r|r|r|c|}
\hline $\begin{array}{l}\text { Mod } \\
\text { el }\end{array}$ & $\mathrm{R}$ & R Square & $\begin{array}{c}\text { Adjusted R } \\
\text { Square }\end{array}$ & $\begin{array}{c}\text { Std. } \\
\text { Error of } \\
\text { the } \\
\text { Estimate }\end{array}$ \\
\hline 1 &, $600^{\mathrm{a}}$ &, 360 &, 321 &, 05526 \\
\hline
\end{tabular}

a. Predictors: (Constant), KM, KI, Profit ,KL

Berdasarkan analisis tabel di atas menunjukkan angka Adjust $R$ Square adalah 0,360 artinya $36 \%$ variabel terikat Pengungkapan CSR yang dijelaskan oleh variabel bebas yang terdiri dari Kepemilikan Manajerial, Kepemilikan Institusional, Profitabilitas dan Kinerja Lingkungan sisanya sebesar $74 \%$ dijelaskan oleh variabel lain diluar variabel yang digunakan. Jadi sebagian besar variabel terikat dijelaskan oleh variabel diluar variabel-variabel bebas yang tidak digunakan dalam model.

\subsection{PEMBAHASAN}

Melihat pengaruh variabel Kepemilikan Manajerial (X1), Kepemilikan Institusional (X2) dan Profitabilitas (X3) dan Kinerja Lingkungan (X4) terhadap Pengungkapan CSR (Y) digunakan analisis regresi berganda dengan persamaan sebagai berikut:

$$
\begin{aligned}
& \mathrm{Y}=0,185+0,38 \mathrm{X} 1+0,037 \mathrm{X} 2+0,051 \mathrm{X} 3+0,065 \\
& \mathrm{X} 4+\mathrm{e}
\end{aligned}
$$

Dari hasil pengolahan data maka semua variabel tersebut diatas menunjukkan adanya pengaruh yang positif dan signifikan, hal ini dapat dilihat dari nilai probabilitas $(\alpha<0,05)$. Model regresi di atas menunjukkan bahwa setiap kenaikan $1 \%$ 
Kepemilikan Manajerial akan meningkatkan Pengungkapan CSR 0,037\%,. Dan sebaliknya jika kepemilikikan Manajerial turun sebesar $1 \%$, maka CSR juga diprediksi mengalami penurunan sebesar 0,037\% dengan anggapan variable Kepemilikan institusional dan Profitabilitas dan Lingkungan Kerja tetap (ceteris paribus)

Kinerja lingkungan merupakan kinerja suatu perusahaan yang peduli terhadap lingkungan sekitar. Kinerja lingkungan dapat dilakukan dengan menerapkan akuntansi lingkungan. Akuntansi lingkungan merupakan pengakuan dan integrasi dampak isu-isu lingkungan pada sistem akuntansi tradisional suatu perusahaan (Halim dan Irawan,1998 ; Fitriyani, 2012). Di Indonesia, kinerja lingkungan dapat diukur dengan menggunakan Program Penilaian Peringkat Kinerja Perusahaan dalam pengelolaan lingkungan (PROPER).

Perusahaan dengan environmental performance yang baik perlu mengungkapkan informasi kuantitas dan mutu lingkungan yang lebih baik dibandingkan perusahaan dengan environmental performance yang lebih buruk (Sudaryanto, 2011; Bahari dan Cahyani, 2016). Hal ini dikarenakan perusahaan sudah mampu menjaga kelestarian lingkungan dan mampu beroperasi dengan baik tanpa adanya pihak-pihak yang dirugikan. Penetapan hubungan antar kinerja lingkungan dengan pengungkapan informasi lingkungan adalah penting dari perspektif tanggung jawab sosial perusahaan. Kinerja lingkungan yang dinilai melalui program PROPER memberikan pengaruh terhadap pengungkapan informasi tanggung jawab sosial perusahaan.

Akuntan menjadi pihak yang penting yang berperan penting karena adanya akses bagi mereka untuk masuk kedalam informasi keuangan sebuah perusahaan. Penilaian serta perhitungan yang dilakukan oleh akuntan akan mempermudah manajer dalam pengambilan keputusan terkait kebijakan pengelolaan serta pelestarian lingkungan. Selain itu, dalam disiplin ilmu pengungkapan akuntansi biaya lingkungan telah lama dirumuskan dan keberadaannya semakin penting. Akuntansi mempunyai peranan penting sebagai media pertanggung jawaban publik atas pengelolaan lingkungan oleh perusahaan Corporate social responsibility (CSR) merupakan salah satu bentuk sustainability reporting yang memberikan keterangan tentang berbagai aspek-aspek perusahaan mulai dari aspek sosial, lingkungan dan keuangan sekaligus yang tidak dapat dijelaskan secara tersirat oleh suatu laporan keuangan perusahaan saja Artinya semakin baik kinerja dari perusahaan maka akan semakin baik pengungkapan CSR dari sebuah perusahaan.

Bangun $d k k$ (2012) menyatakan bahwa semakin tinggi tingkat kepemilikan manajemen, semakin tinggi pula motivasi untuk mengungkapkan aktivitas perusahaan yang dilakukan. Kepemilikan manajemen berpengaruh positif terhadap pengeluaran program $C S R$, namun pada suatu titik tertentu hal tersebut dapat mengurangi nilai perusahaan dan batasan yang telah dicapai sehingga menyebabkan suatu hubungan negatif.

Penelitian ini tidak mendukung penelitian dari Grief dan Zychowicz (1994) ; Rawi (2008) bahwa kepemilikan institusional yang tinggi dari persentase saham yang dimiliki oleh institutional investor akan menyebabkan tingkat monitor lebih efektif, dengan demikian semakin tinggi kepemilikan institusi, maka untuk program CSR terbatas. Sembiring (2005) menyatakan bahwa kepemilikan saham oleh publik berpengaruh negatif signifikan terhadap pengungkapan tanggung jawab sosial perusahaan. Sedangkan, Bangun $d k k$ (2012) menyatakan bahwa semakin besar persentase kepemilikan publik semakin luas dalam pengungkapan sukarela dalam laporan keuangan tahunan.

\section{SIMPULAN DAN SARAN}

\subsection{Kesimpulan}

Bedasarkan analisis hasil penelitian dan pembahasan yang telah diuraikan sebelumnya maka dapat disimpulkan sebagai berikut:

1. Hasil analisis regresi berganda menunjukan bahwa terdapat pengaruh Kepemilikan Manajerial, kepemilikan Institusional, Profitabilitas , dan Kinerja lingkungan berpengaruh secara simultan terhadap pengungkapan Corporate Social Responsibility (CSR) pada Perusahaan Pertambangan Di BEI.

2. Kepemilikan manajemen adalah proporsi pemegang saham dari pihak manajemen yang secara aktif ikut dalam pengambilan keputusan perusahaan Dengan adanya kepemilikan manajemen dalam perusahaan maka dapat menimbulkan dugaan bahwa nilai perusahaan dapat meningkat jika kepemilikan manajemen meningkat Dari hasil analisis regresi berganda uji menunjukkan bahwa terdapat pengaruh Kepemilikan Institusional terhadap Pengungkapan CSR.

3. Kepemilikan institusional merupakan saham perusahaan yang dimiliki oleh institusi atau lembaga (perusahaan asuransi, bank, perusahaan investasi dan kepemilikan institusi lain). Masalah keagenan utama dalam perusahaan adalah konflik antara pemegang saham pengendali dengan pemegang saham minoritas. Dari hasil analisis regresi berganda menunjukkan bahwa terdapat pengaruh Kepemilikan Institusional terhadap Pengungkapan CSR.

4. Setiap perusahaan mengharapkan mendapatkan profit atau laba yang maksimal. Profitabilitas 
merupakan suatu perhitungan yang bertujuan untuk mengetahui tingkat laba diperoleh perusahaan berdasarkan komponen-komponen yang ada dalam perusahaan tersebut. Dari hasil analisis regresi berganda menunjukkan bahwa terdapat pengaruh Profitabilitas terhadap Pengungkapan CSR.

5. Kinerja lingkungan merupakan kinerja suatu perusahaan yang peduli terhadap lingkungan sekitar. Kinerja lingkungan dapat dilakukan dengan menerapkan akuntansi lingkungan. Akuntansi lingkungan merupakan pengakuan dan integrasi dampak isu-isu lingkungan. Dari hasil analisis regresi berganda uji menunjukkan bahwa terdapat pengaruh kinerja lingkungan terhadap Pengungkapan CSR.

\subsection{Saran}

Berdasarkan kesimpulan dan keterbatasan diatas, maka dapat diberikan saran sebagai berikut: Sebagai peneliti pemula tentunya penelitian ini memiliki banyak keterbatasan.Sebagai bahan pertimbangan untuk melakukan penelitian berikutnya agar hasil yang diperoleh lebih baik berikut beberapa keterbatasan dalam penelitian ini.

\subsubsection{Saran Praktis}

1. Perusahaan tambang hendaknya dapatmeningkatkan kinerja corporate social responsibility (CSR) dengan menerapkan berbagai kegiatan yang sesuai dengan yang digariskan dalam pedoman GRI G4 secara menyeluruh dan maksimal, dalam hal ini juga termasuk dalam hal pelaporan secara berkala sehingga dapat digunakan oleh stakeholder untuk mengukur sejauh mana pelaksanaan CSR oleh perusahaan.

2. Perusahaan harus meningkatkan kinerja prusahaan dalam hal ini meningkatkan kinerja yang baik seperti dengan memberikan pelatihan yang berkala sehingga dapat menciptakan lingkungan yang kondusif dan akan berimbas dengan baiknya pelaksanaan CSR oleh perusahaan

\subsubsection{Saran Akademis}

1. Penelitian selanjutnya hendaknya menggunakan semua jenis perusahaan, sehingga sampel yang digunakan dapat mewakili semua karakteristik dalam populasi dan dapat mencerminkan kenyataan yang sesungguhnya.

2. Periode pengamatan pada penelitian selanjutnya hendaknya lebih diperpanjang yaitu lebih dari satu tahun, sehingga hasil penelitian mencerminkan fenomena yang sesungguhnya dan hasil penelitian akan lebih baik.

3. Penelitian selanjutnya dapat menambah variabel lainnya karena sangat dimungkinkan ada variabel lainnya yang lebih berpengaruh terhadap pengungkapan CSR dalam laporan keuangan seperti umur perusahaan, harga pasar saham, dan lain-lain.

4. Pada penelitian berikutnya agar dilakukan uji analisis path untuk mengetahui apakah ada faktor faktor yang menjadi pendukung dan hambatan dalam pelaksanaan atau Pengungkapan CSR.

\section{DAFTAR REFERENSI}

Anggraini, R. Fr. 2006. Pengungkapan Informasi Sosial dan Faktor-Faktor yang Mempengaruhi Pengungkapan Informasi Sosial dalam Laporan Keuangan Empiris pada Perusahaan-Perusahaan yang Terdaftar di Bursa Efek Jakarta". Simposium Nasional Akuntansi 9 Padang (KAKPM 24). Hlm 1-21.

Al-Tuwajiri, dan Sulaiman. 2004. The Relation Among Environmental Disclosure, Environmental Performance, dan Economic Performance: A Simultenaous Equation Approach. Accounting Environment Journal.USA. 5-10.

Bahri, Syaiful dan Cahyani, Febby Anggista.2016. Pengaruh Kinerja Lingkungan Terhadap CorporateFinancial Performance Dengan Corporate Social Responsibility Disclosure Sebagai Variabel Intervening (Studi Empiris Pada Perusahaan Manufaktur Yang Terdaftar Di Bei). Jurnal EkoNiKa |Vol. 1, No. 2, September 2016.

Bahri, Syaiful dan Cahyani, Febby Anggista.2016. Pengaruh Kinerja Lingkungan Terhadap Corporate Financial Performance Dengan Corporate Social Responsibility Disclosure Sebagai Variabel Intervening (Studi Empiris Pada Perusahaan Manufaktur Yang Terdaftar Di Bei). Jurnal EkoNiKa Vol. 1, No. 2

Brigham Eguene F dan Joel F. Houston. 2006. Dasardasar Manajemen Keuangan. Salemba Empat: Jakarta.

BEI. 2018. IDX Yearly Statistics 2015- 2017. Indonesia Stock Exchange

Bangun, Nurainun., Juwita Octavia dan Krisnawati Br Tarigan. 2012. Pengaruh Kepemilikan Manajerial, Kepemilikan Institusional dan Profitabilitas terhadap Pengungkapan Corporate Social Responsibility pada Perusahaan yang Terdaftar di Bursa Efek Indonesia .Jurnal Akuntansi.Vol 12, Nomor 2, Hal 717-738.

Eva, Sriviana. (2013). Pengaruh Pengungkapan Corporate Social Responsibility dan Ukuran Perusahaan terhadap Profitabilitas. Jurnal Ilmu \& Riset Akuntansi. Vol. 2, No. 4, pp 1-16. 
Ghozali, I dan Chariri, A 2007. Teori Akuntansi. Semarang. Badan Penerbit UNDIP

Ghozali, Imam. 2011. Aplikasi Analisis Multivariate dengan Program SPSS. Edisi 3.Semarang: Badan Penerbit Universitas Diponegoro..

Hadi, Nor. 2011. Corporate Social Responsibility. Yogyakarta: Graha Ilmu

Hanfi, Mamduh M, dan Halim, A. 2009. Analisis Laporan Keuangan. Edisi Keempat. Yogyakarta: Sekolah Tinggi Ilmu Manajemen YKPN

Hasibuan, Chysanti, Sedyono. 2006. CSR Comunication: A Challenge On Its Own, Economics Business Acounting Review. Edisi III, September-Desember 2006

Haruman, Tedi. 2008. Pengaruh Struktur Kepemilikan Terhadap Keputusan Keuangan dan Nilai Perusahaan. Simposium Nasional Akuntansi XI, Pontianak.

Karima, Nadia. 2014. Pengaruh Kepemilikan Manajerial, Kepemilikan Institusional Dan Kepemilikan Asing Terhadap Pengungkapan Tanggung Jawab Sosial Perusahaan. Widya Warta No. 02 Tahun XXXVIII/Juli 2014 ISSN 0854-1981

Kementrian Lingkungan Hidup. 2016. Pedoman CSR Bidang Lingkungan. Mentri

Negara Lingkungan Hidup.

Leimona, B., \& Fauzi, A. (2008). CSR dan Pelestarian Lingkungan Mengelola Dampak: Positif dan Negatif

Kasali, Renald. 2003. Manajemen Public Relations: Konsep dan Aplikasinya di Indonesia. Jakarta: PT. Pustaka Utama Grafiti

Kotler, Philip and Nancy Lee. 2005. Corporate Social Responsibility, Doing the Most Good For Your Company and Your Cause. New Jersey: John Wiley

Luthan, Elvira. 2010. Keterkaitan Antara Corporate Sosial Responsibility (CSR) dan Good Corporate Governance (GCG) dalam meningkatkan Kinerja perusahaan. Bandung: UNPAD Press

Mulkhan, Unang.2013.Corporate Sustainability Reporting: A Content Analysis of CSR Reporting in Indonesia. Jurnal Perspektif Bisnis, Vol 1. ISSN 2338-5111

Putra, Eka Maulana Nugraha.2012. Analisis Pengaruh Pengungkapan Corporate Social Responsibility (CSR) terhadap tingkat Profitabilitas Perusahaan. Studi Empiris pada Industri Agriculture yang terdaftar di Bursa Efek Indonesia.BINUS University.Jakarta
Rahayu, wiwiek, Darminto dan Topowijono. 2014. Pengaruh Pengungkapan Corporate Social Responsibility (CSR) Terhadap Profitabilitas Perusahaan (Studi Pada Perusahaan Sektor Pertambangan Periode 2012-2013 Yang Terdaftar Di Bursa Efek Indonesia). Jurnal Administrasi Bisnis (Jab) Vol. 17 No. 2

Ratnasari, Yunita. 2011. Pengaruh Corporate Governance terhadap Luas Pengungkapan Tanggung Jawab Sosial Perusahaan di dalam Sustainability report. Jurnal. Universitas Diponegoro Semarang

Rawi. 2008. Pengaruh Kepemilikan Manajemen, Institusi dan Laverage terhadap Corporate Social Responsibility (CSR) pada perusahaan Manufaktur yang Listing di Bursa Efek Indonesia. Tesis Undip: Semarang.

Suharto, Edi. 2010. CSR \& COMDEV. Bandung: Alfa Beta

Sayekti Yosefa, dan Ludovasicus Sensi Wondabio. (2007). Pengaruh CSR Disclosure terhadap Earning Response Coefficient. Simposium Nasional Akuntansi ke-10.Makasar, 26-28 J

Purwanto, A. 2011. Pengaruh Tipe Industri, Ukuran Prusahaan, Profitabilitas Terhadap Corporate Social Responsibility. Jurnal

Akuntansi \& Auditing Vol 8/No. 1/ hal.1-94

Undang-Undang Republik Indonesia. Peraturan Pemerintah Nomor 40 Tahun 2007 Tentang Tanggung Jawab Sosial dan Lingkungan Perseroan Terbatas

Utami, Sri. 2011. Pengaruh Karakteristik Perusahaan terhadap Social Disclousure. Jurnal Ekonomi Bisnis TH. 16, No. 1, Maret.

Wibisono, Yusuf.2007. Membedah Konsep dan Aplikasi CSR. Gresik : Fascho Publishing

Wibowo,Soni. 2016. Pengaruh Kepemilikan Manajemen, Kepemilikan Institusional, Kebijakan Deviden, Kebijakan Hutang terhadap Nilai Perusahaan. Tesis Universitas Airlangga.

www.idx.co.id. Diakses tanggal 16 November 2018

Ratnasari, Yunita. 2011. Pengaruh Corporate Governance terhadap Luas Pengungkapan Tanggung Jawab Sosial Perusahaan di dalam Sustainability report. Jurnal. Universitas Diponegoro Semarang

Rawi. 2008. Pengaruh Kepemilikan Manajemen, Institusi dan Laverage terhadap Corporate Social Responsibility (CSR) pada perusahaan Manufaktur yang Listing di Bursa Efek Indonesia. Tesis Undip: Semarang.

Suharto, Edi. 2010. CSR \& COMDEV. Bandung: Alfa Beta 2014. 